ISSN1027-5495. Functional Materials, 23, No.1 (2016), p. 132-137.

doi:http://dx.doi.org/10.15407/fm23.01.132

(C) 2016 - STC “Institute for Single Crystals"

\title{
Experimental and theoretical analysis of fatigue properties of liner for the large pressure equipment
}

\author{
Feng Xianzhang, Cheng Junwei, \\ Cui Yanmei, Jiang Zhiqiang
}

\author{
School of Mechanical Engineering, Zhengzhou Institute of Aeronautical \\ Industry Management, Zhengzhou,Henan, 450015, P.R. China
}

\section{Received July 3, 2015}

In order to analyze the working status of the key components of large-width device online, taking liners force status as the object of study before and after reformation of the liners. Specifications for the slab: $230 \mathrm{~mm} \times 1300 \mathrm{~mm} \times 2600 \mathrm{~mm}$, the initial temperature is $1020 \mathrm{C}$, the amount of lateral pressure is $228 \mathrm{~mm}$, and the angle of the die is $12^{\circ}$. Using the main tool of frequency fatigue testing machine with the model of PLG-100C, based on the principle of up and down, and it can obtain the distribution rulers of testing and experimental by the method of directly stick the strain chip on the liners. The result of study indicates that it can provide the theoretical basis for the reformation of the liner and the analysis of stress state of large the lateral pressure equipment.

Keywords: Large the lateral pressure equipment, frequency fatigue, liner, stress distribution, stress state.

Для текущего анализа рабочего состояния ключевых компонентов устройства большой ширины принят силовой статус направляющих втулок, как объекта исследования до и после их переформирования. Размеры пластины: 230х1300х2600 мм, исходная температура $1020^{\circ} \mathrm{C}$, ширина латерального давления 228 мм, угол пуансона $12^{\circ}$. Используя основную функцию устройства для испытаний на частотную усталость модели PLG-100C, основанной на принципе «вверх-вниз», можно получить линейки распределений для испытаний и экспериментов методом непосредственного присоединения пластинки напряжения к втулке. Результаты показывают, что это может быть теоретической основой переформирования втулки и анализа напряженного состояния оборудования для латерального прессования.

Експериментальний і теоретичний аналіз утомних властивостей напрямного втулку для обладнання для високих тисків. Фен Сяньчжан, Чен Цзюнвей, Цуй Яньлей, Цзян Чжииян.

Для поточного аналізу робочого стану ключових компонентів пристрою великої ширини прийнято силовий статус напрямних втулків як об’єкту досліджень до і після їх переформування. Розміри платівки 230x1300x2600 мм, висхідна температура $1200^{\circ} \mathrm{C}$, ширина латерального тиску 228 мм, кут пуансона $12^{\circ}$. Використовуючи основну функцію пристрою для тестування на частотну втому моделі PLG-100C, що базуеться на принципі «вгору-вниз», можна отримати лінійки розподілу для тестувань та експериментів методом безпосереднього під'єднання пластинки напруг до втулка. Результати показують, що це може бути теоретичною основою переформування втулку та аналізу напруженного стану обладнання для латерального пресування. 


\section{Introduction}

The lateral pressure online is similar with the process of free forging in the rolling workshop[1-8], it has a greater impact load during working. The liner situated at the bottom of lateral pressure mechanism, and connects with the lateral pressure module by the screws. According to fault reporting of plant, the surface of liner has multiple cracks, in which lie in export side of rolling mill' . The mill need to stop more than eight hours for the accident because of liner, to lead the seriously affected the production when replace the new liner [10-12].

The pressure equipment has two sets of lateral pressure mechanism, in which have three liners for one pressure equipment, to withstand the weight of the lateral pressure module and the surface of the frame of lateral pressure module, the lower surface of the liners contact with the support wheels, and slip on the support wheels in process of rolling. Under the effect of weight of the lateral pressure module and the frame of lateral pressure module, the liner can be simplified to beam bending, when the support wheels in the fixed location[13-15]. The liners suffered the biggest moment and large contact stress in the contact area of support wheels and liners, the liner is damaged by the factors together[16-20].

\section{Test analysis}

To fully investigate the stress state of the liners, a total of 18 groups of strain gauges ware glued on the both sides of the framework, the layout of strain gauges are shown in Fig. 1.

However, due to the liner lie in the lower framework, the place is a bad environment, the liner is belong to moving parts in working, there is many the problems of wire fixed connecting the strain gauges on the liner, the impact of cooling water and lubricants corrosion, etc. These more unfavorable factors lead to some of the strain gauge unable to work normally.

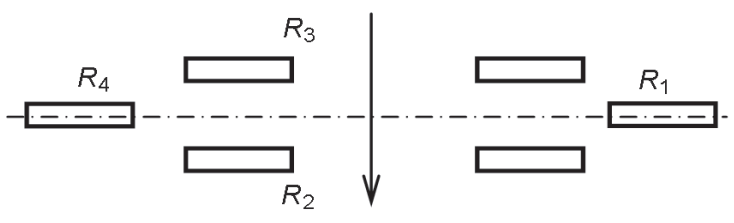

Fig. 1. The layout of strain gauges

Because of the free end in edge of liner, the value of the stress and strain is very small, and not truly reflects the internal state in liner, but the stress can be as boundary condition of the finite element analysis, it is more important to reflect stress changes during the rolling for the lateral pressure device.

Strain waveform of the in process of rolling for the continuous casting slab is shown in Figure 2.

The Figure 2 shows that: the main force acting on liners with the weight side pressure device and moving along the support wheel, it can output the stress waveform, once the pressure on the liners. The amplitude of waveform of stress is more increase because of in the direction of gravity, the amplitude of waveform of stress is more decrease after the process of rolling.

\section{Experimental preparation}

\subsection{Selection specimens}

Taking the 13 groups from the specimens of the old liner, the 12 groups from the specimens of the new liner, and making them as the object of test and study, the part of the old liner and physical specimen are shown in Figure 3.

The Figure 2 shows that: the up picture is on behalf of scrapped liner, the down picture is on behalf of specimen, because it can not directly access the whole linier of the fatigue strength, based on the similarity theory, at first get specimen fatigue strength through test method,

Waveform Graph

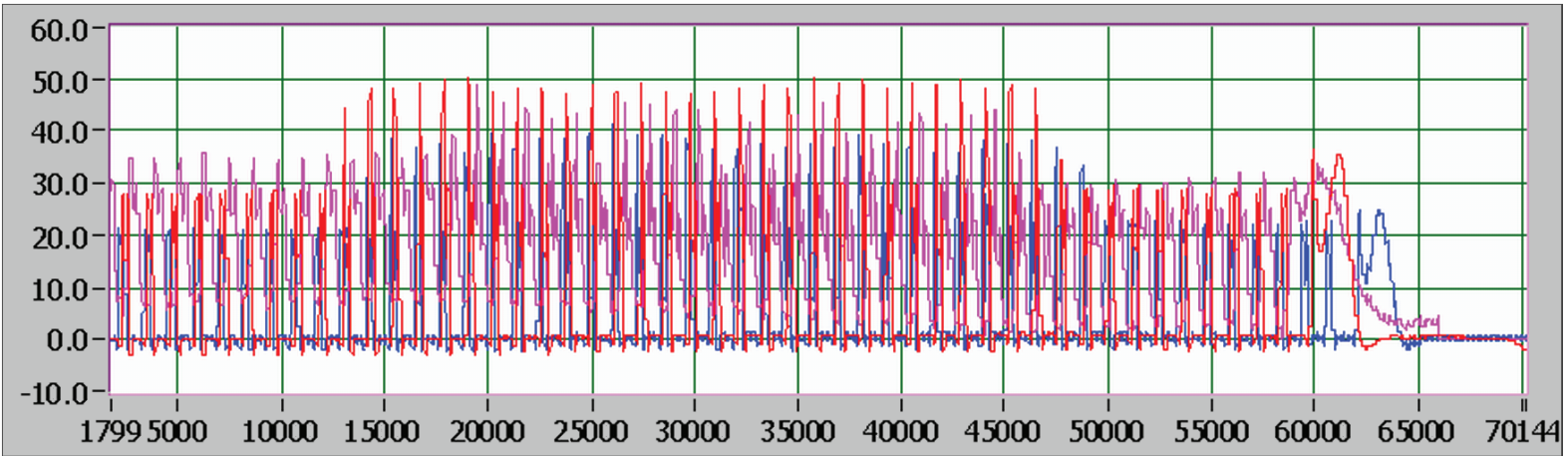

Fig. 2. Response waveform 

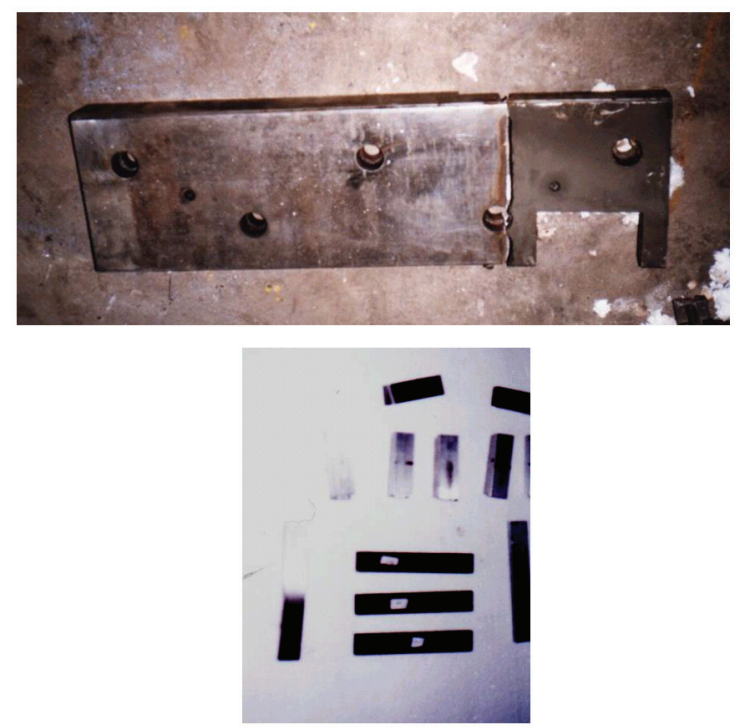

Fig. 3. The photographs of liner and specimens.

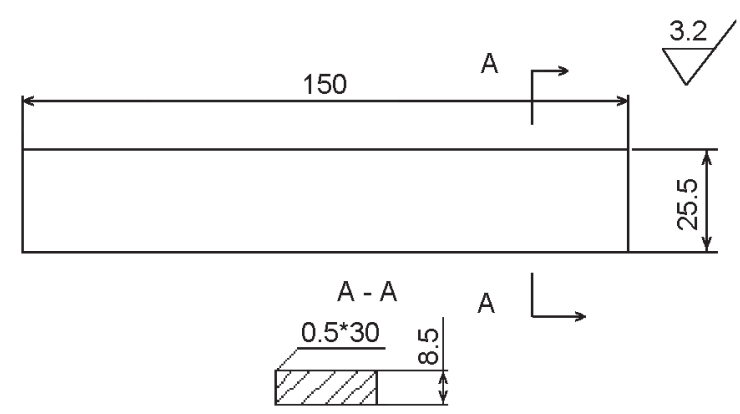

Fig. 4.The dimension of specimens.

and then combined with relational knowledge of relevant the fatigue.

The dimension of the specimens for fatigue testing is shown in Figure 4.

\subsection{Experimental plan}

According to the state of liner in process of working, using the method of the three points bending to applied the load for fatigue tests, the schematic diagram of load test is shown in Figure 5.

According to relational theory of mechanics of materials. Under the loading mode of shown in Figure 5. The maximum stress can be expressed as.

$$
\sigma_{\max }=M_{\max } / W_{b}
$$

Where $M_{\max }$ is the maximum moment' $P_{\max }$ is the maximum load, $W_{b}$ is bending crosssection factor, for the rectangular specimen, $W_{b}=b h^{2} / 6$.

The maximum moment can be expressed as.

$$
M_{\max }=P_{\max } L / 4
$$

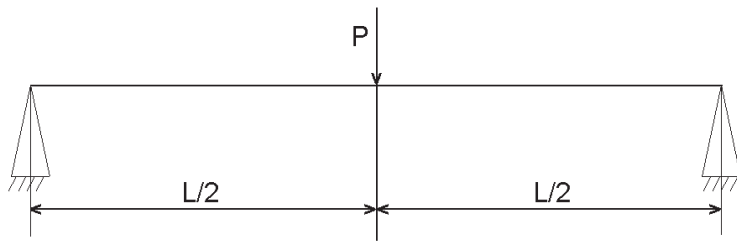

Fig. 5. Loading mode.

Where $b$ is the width of the specimen, $b=25.5$ $\mathrm{mm}, h$ is height of the specimen, $h=8.5 \mathrm{~mm}$.

Analysis (1) and 2 can be extrapolated, the maximum moment in the specimen can be expressed as.

$$
\sigma_{\text {max }}=3 P_{\text {max }} L / 2 b h^{2}
$$

The maximum stress in the specimen can be expressed as.

$$
P_{\text {max }}=2 \sigma_{\text {max }} b h^{2} / 3 L
$$

\subsection{Results of Experimental Analysis}

The method of up and down was adopted in the process of measuring for the specimens fatigue, The so-called lifting method is that the fatigue limit stress level was loaded with higher or lower than the estimated fatigue limit stress, and then make the load to reduce or increase. If the first specimen occurred damage before not meet the specified life under the stress, then the second specimen is tested under the lower level of stress. If the first specimen is no damage after meeting the specified life under the stress, then the second specimen is tested under the higher level of stress. Repeatedly do it in the ruler, until find the limit of fatigue

Fatigue load with the mode of up and down of the specimen is shown in Figure 6.

The fatigue testing results of old liner is shown in Table 1.

The fatigue testing results of new liner is shown in Table 2.

Analysis of Table 1 and Table 2 cam shows: the two tests can be considered as two independent samples groups, it deduce the general characteristics of the corresponding figures by the number of characteristics of the sample in mathematical tools. So eventually estimate the fatigue strength of liner by the statistics and analysis of fatigue strength of specimen.

In the testing, the turning point of the first "break- continuous" or "constantly-off" is the starting point of the stress test, and then determines the low-frequency events. Take the specimen break as the LEF, the low-frequency 
Feng Xianzhang et al. / Experimental and theoretical analysis ...

Table 1. The Fatigue testing result of old liner

\begin{tabular}{c|c|c|c}
\hline No. & Stress/MPa & $\begin{array}{c}\text { Cycles } \\
\text { times/N }\end{array}$ & Results \\
\hline 1 & 800 & 125017 & Break \\
\hline 2 & 700 & 134613 & Break \\
\hline 3 & 660 & 185411 & Break \\
\hline 4 & 640 & 10000000 & Good \\
\hline 5 & 660 & 416362 & Break \\
\hline 6 & 640 & 518276 & Break \\
\hline 7 & 620 & 326283 & Break \\
\hline 8 & 600 & 10000000 & Good \\
\hline 9 & 620 & 10000000 & Good \\
\hline 10 & 640 & 147529 & Break \\
\hline 11 & 620 & 10000000 & Good \\
\hline 12 & 640 & 10000000 & Good \\
\hline 13 & 660 & 223562 & Break \\
\hline
\end{tabular}

Table 2. Fatigue testing result of new liner board

\begin{tabular}{|c|c|c|c|}
\hline No. & $\begin{array}{c}\text { Stress/ } \\
\text { MPa }\end{array}$ & $\begin{array}{c}\text { Cycles } \\
\text { times/N }\end{array}$ & results \\
\hline 1 & 660 & 10000000 & Good \\
\hline 2 & 690 & 10000000 & Good \\
\hline 3 & 720 & 10000000 & Good \\
\hline 4 & 750 & 10000000 & Good \\
\hline 5 & 780 & 10000000 & Good \\
\hline 6 & 810 & 3304125 & Break \\
\hline 7 & 780 & 1574730 & Break \\
\hline 8 & 750 & 10000000 & Good \\
\hline 9 & 780 & 10000000 & Good \\
\hline 10 & 810 & 10000000 & Good \\
\hline 11 & 840 & 2156712 & Break \\
\hline 12 & 810 & 10000000 & Good \\
\hline
\end{tabular}

events of testing for the old specimen liner is shown in Table 3.

The low-frequency event of testing for the new specimen liner is shown in Table 4.

In Tables 3 and 4 , the column 1 is experienced stress level of LEF, the " 0 " of the column 2 is lowest stress level of LEF, the "1" is higher
Table 3. LEF event of old liner board sample

\begin{tabular}{|c|c|c|c|c|}
\hline 1 & 2 & 3 & 4 & 5 \\
\hline 600 & 0 & 0 & 0 & 0 \\
\hline 620 & 1 & 1 & 1 & 1 \\
\hline 640 & 2 & 2 & 4 & 8 \\
\hline 660 & 3 & 3 & 9 & 27 \\
\hline
\end{tabular}

Table 4. LEF event of new liner board sample

\begin{tabular}{|c|c|c|c|c|}
\hline 1 & 2 & 3 & 4 & 5 \\
\hline 750 & 0 & 0 & 0 & 0 \\
\hline 780 & 1 & 1 & 1 & 1 \\
\hline 810 & 2 & 1 & 2 & 4 \\
\hline 840 & 3 & 1 & 3 & 9 \\
\hline
\end{tabular}

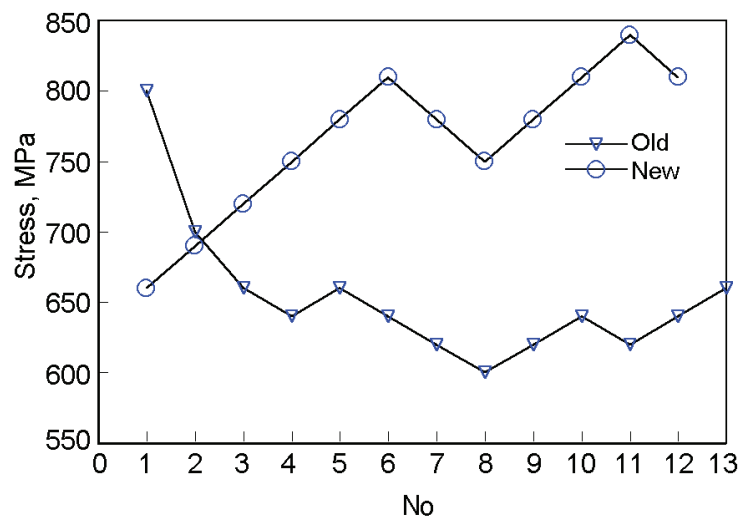

Fig. 6. The curve of fatigue loading.

stress level of LEF, and the " 2 " is higher stress level of LEF, and so on.

The column 3 is times of occurrences in the stress state, the column 4 is product by the column 2 and the column 3 , the column 5 is product by square of the column 2 and the column 3 , the mark "A" is a representation of the sum the column 4 , the mark " $\mathrm{B}$ " is a representation of the sum the column 5 , the mark "N" is times of LEF (the sum the column 3)

There are:

For the old liner specimens:

$$
A=14, B=36, N=6
$$

For the new liner specimens:

$$
A=6, B=14, N=3
$$

The statistics fatigue limit can be expressed as

$$
s_{m}=s_{0}+d\left[\frac{A}{N} \pm \frac{1}{2}\right]
$$


Where $s_{0}$ is the lowest stress level of LEF' $d$ is step of stress.

The formula (5) select positive sign, when the specimens is no fracture, otherwise select negative sign,

The $d$ of overall standard deviation is as following:

$$
\begin{gathered}
\frac{N B-A^{2}}{N^{2}} \geq 0.3 \\
\delta=1.62 d\left\{\frac{N B-A^{2}}{N^{2}}+0.029\right\} \\
\frac{N B-A^{2}}{N^{2}}<0.3 \delta=0.55 d
\end{gathered}
$$

From (6) and (7) shows,

For the specimen of the old liner, it can be derived

$$
\frac{N B-A^{2}}{N^{2}}=\frac{6 \times 36-14^{2}}{36}=0.556
$$

From (6), the value of the overall standard deviation is as following:

$$
\delta=2 \times 20\{0.556+0.029\}=18.954(\mathrm{MPa})
$$

For the specimen of the new liner,

$$
\frac{N B-A^{2}}{N^{2}}=\frac{3 \times 14-36}{9}=0.667
$$

From (6), the value of the overall standard deviation is as following:

$$
\begin{gathered}
\delta=1.62 \times 30 \times\{0.667+0.029\}= \\
=33.83(\mathrm{MPa})
\end{gathered}
$$

The $\delta_{m}$ of standard deviation $S_{m}$ can be expressed as.

$$
\delta_{m}=\left(\frac{G}{\sqrt{N}}\right) \delta_{0}
$$

Where $\delta_{0}$ is estimates overall standard deviation, $\mathrm{G}$ is confidence factor, the linear function of $d / s$ determined from Figure 7 .

For the specimen of the old liner:

$$
d=20, \delta=\delta_{0} \times 18.954^{\prime} d / \delta \times 1.06 .
$$

From the Figure 7.

$$
\mathrm{G}=1.05^{\prime} \delta_{m}=1.05 / \sqrt{6} \times 18.954=8.125(\mathrm{MPa})
$$

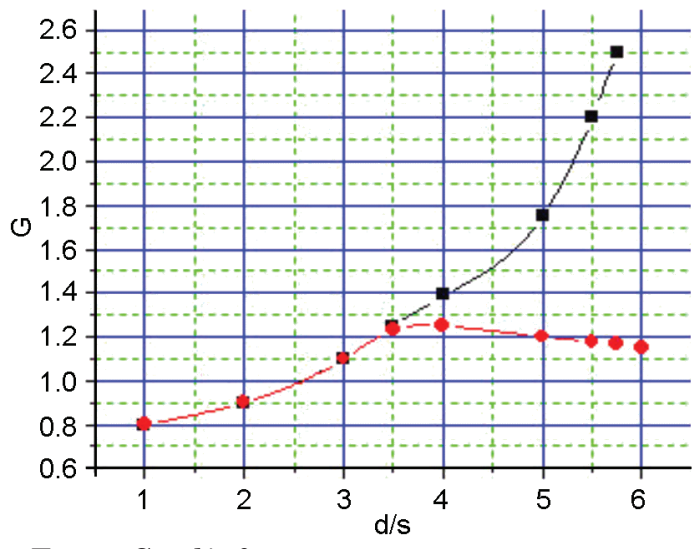

Fig. 7. $\mathrm{G}-\mathrm{d} / \mathrm{s}$ function curve.

For the specimen of the new liner:

$$
d=30, \delta=\delta_{0} \times 33.83^{\prime} d / \delta \times 0.9
$$

From the Figure.

$$
\mathrm{G}=0.98^{\prime} \delta_{m}=0.98 / \sqrt{3} \times 33.83=19.14(\mathrm{MPa})
$$

The true fatigue limit of the specimen at a given confidence interval $\mu$ can be expressed as:

$P\left\{S_{m}-Y_{0} \delta_{m} \leq \mu \leq S_{m}+Y_{0}\right\}=100(1-\alpha)$

Where $\alpha$ is the factor of effective level of specimen, $\alpha=0.05$.

With the corresponding of $Y_{0}$ and $\alpha$ in the $95 \%$ confidence interval, if the $\alpha=0.05$, then, $Y_{0}=1.96$ by the look-up table of standard normal distribution.

Old test specimen liner confidence interval can be expressed as.

$$
\begin{aligned}
& \mathrm{P}\{636.667-.96 \times 8.125 \leq \mu \leq 636.667+ \\
& +1.96 \times 8.125\}=\{620.74 \leq \mu \leq 652.59\}
\end{aligned}
$$

New test specimen liner confidence interval can be expressed as.

$$
\begin{gathered}
\mathrm{P}\{795-1.96 \times 19.14 \leq \mu \leq 95+1.96 \times 19.14\}= \\
=\{757.5 \leq \mu \leq 832.5\}
\end{gathered}
$$

\section{Conclusions}

It can obtain the range of limit fatigue strength from 181 to $190 \mathrm{MPa}$ of the old liner, and the range of limit fatigue strength from 221 to $243 \mathrm{MPa}$ for the new liner. The maximum calculated stress is $341 \mathrm{MPa}$ before reformation of the liner by analyzing the fatigue limit of the old and the new liners, the value was significantly greater than the fatigue limit strength, it can be concluded that the reasons of liner fracture is belong to fatigue fracture be- 
fore reformation of the liner. The calculation of the maximum stress liner is only $176 \mathrm{MPa}$ after reformation of the liner, it make the liner of the force greatly improved for the method of the transformation, but also improve the liner useful life.

\section{Acknowledgements}

This work is partially supported by the Assistance Scheme of Young Backbone Teachers of Henan Province Colleges and Universities (2010GGJS-147), Science and Technique Foundation of Office of Education of Henan Province (14A460014),"HASTIT" (2012HASTIT023) and "IRTSTHN" (2012IRTSTHN014, 14IRTSTHN003)

\section{References}

[1] N.Bernet, M. D. Wakeman, P. E. Bourban, Composites Part A, 33, 495, 2002.

[2] F. Xianzhang, W. Lihong, Yu. Lihong, J. Comp. Inform. Syst, 6, 2451, 2007

[3] L. Yuli, L. Won-Ho., ISIJ International, 45, 2005.

[4] L. Cai, J. Yanshan UNIV., 22, 23, 1998,

[5] W. Lin-feng, Chen De-liang, W. Kai, Coal Mine Machinery, 1, 23, 2007.

[6] Xianzhang Feng, Junwei Cheng, J. Software, 6, $72,2011$.

[7] Gusn Tian-min, Zhang Dong-sheng, Lei Lei, J. Machine Design, 3, 8, 2005.

[8] Bai Zhen hua, Lian Jia chuang, Heavy Machinery, 2002, 5-7.

[9] A. Kaharaman, R Singh, J. Sound Vibr., 146, $135,1999$.

[10]Xianzhang Feng, Yi Wang, Iron Steel, 3, 16, 2008.

[11] Han Yali, Li. Changlin., Mechan. Managm. Devol, 10, 1995, 2008,

[12] Xianzhang Feng, J. Comp., 5, 1388, 2010,

[13] S. C. Shyu, Chang Typ, A. F. Saleeb, Comp. Struct., 2, 223, 1989,

[14]Xianzhang Feng, Hui Zhao, Lecture Notes in Electrical Engineering, 72, 547, 2010.

[15] Hiroaki Kawasaki, Douglas, SAE Paper, 2014, 2002-01-1198.

[16] J. R. Bredell, D. G, Kroger, Appl. Therm. Eng., 26, 846, 2006.

[17] Huang Zhigang, Ke Yinglin, Wang Litao, China Mech. Eng., 14, .846, 2003,

[18] S. C. Shyu, Typ. P. Chang , A. F. Saleeb Comp.. Struct.,32, 223,1989,

[19] F. L. Litvin, G. Argentieri, et.al., Comput. Meth. Appl. Mech. Engrg.189, 785, 2000,

[20] Ligang Yao, Jian S. Dai, Guowu Wei, J. Mech. Design, Trans. ASME, 128, 610, 2006, 